\title{
Comparison of definitive chemoradiotherapy and surgical results in local advanced (stage Illa and IIIb) non-small cell lung cancer: single-center experience
}

\section{Lokal illeri (Evre IIIA ve \|IIB) küçük hücreli dış॥ akciğger kanserinde definitif kemoradyoterapi ile cerrahi sonuçlarının karşılaştırılması: Tek merkez deneyimi}

\author{
Mukaddles Yılmaz', Birsen Yücel², Derya Kirman³, Orhun Akdoğan, Ozan Yazıcı
}

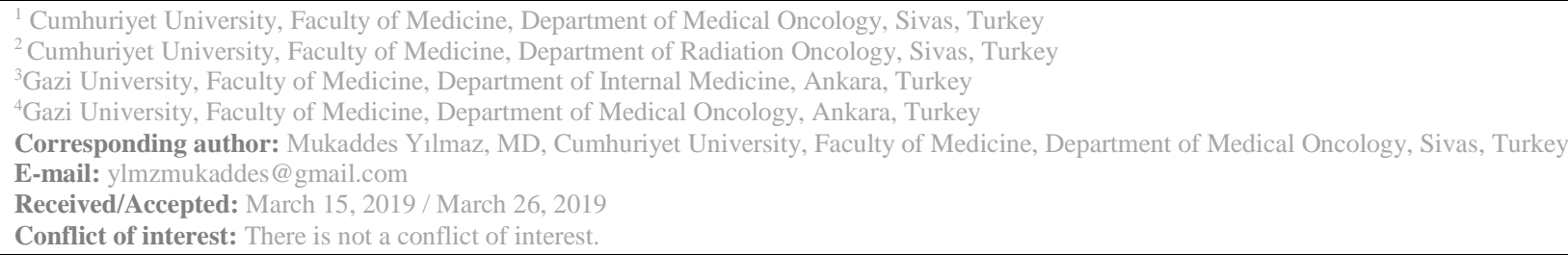

\section{SUMMARY}

Objective: Discussions regarding the treatment of stage III non-small cell lung cancer (NSCLC) are still ongoing in the literature. It is important to evaluate the developments in radiotherapy and surgery along with the data in real life regarding stage III NSCLC. The aim of this study is to evaluate the treatment approaches and real-life data in stage IIIA and IIIB local advanced NSCLC.

Method: The files of 47 patients with local advanced stage IIIA and IIIB NSCLC, who were followed up in the Gazi University Faculty of Medicine, Medical Oncology Clinic between February 2016 and May 2018, were retrospectively evaluated.

Results: As the primary treatment, definitive chemoradiotherapy (CRT) to $27(57 \%)$ patients and surgical treatment to $20(43 \%)$ patients were applied. It was observed that the performance status $(\mathrm{p}=0.010)$ of the patients who underwent CRT was statistically significantly worse, active smoking $(\mathrm{p}=0.033)$ was higher, and had a more advanced lymph node stage $(\mathrm{p}=0.052)$. In the univariate analysis, it was determined that lymph node status $(\mathrm{p}=0.011)$, performance status of the patients $(\mathrm{p}=0.0247)$, and treatment modality of patients $(\mathrm{p}=0.001)$ were the prognostic factors affecting survival. The 1-year overall survival rates and median survival of the patients were $85 \%$ and 23 months in the surgical group respectively, and $41 \%$ and 10 months in the definitive CRT group. In the multivariate analysis, surgery was found to be a better independent prognostic factor than CRT (HR: 2.72, 95\% CI: 1.27-5.82, p=0.010).

Conclusions: It was observed that the results of the patients, who were found to be respectable as a result of the clinical experience in stage III NSCLC patient group, were better. The mediastinal lymph node involvement site, especially N3 lymph node site, and the patient performance are among the important factors that determine the prognosis in stage III NSCLC.

Keywords: Non-small cell lung cancer, surgery, chemoradiotherapy

\section{ÖZET}

Amaç: Literatürde evre III küçük hücreli dışı akciğer kanseri (KHDAK) tedavisi ile ilgili tartışmalar halen sürmektedir. Radyoterapi ve cerrahideki gelişmeler ile evre III KHDAK gerçek yaşamdaki verilerin değerlendirilmesi önem arz etmektedir. Evre IIIA ve IIIB lokal ileri KHDAK'nde tedavi yaklaşımlarının ve gerçek yaşam verilerinin değerlendirilmesi amaçlanmıştır.

Yöntem: Şubat 2016 - Mayıs 2018 tarihleri arasında Gazi Üniversitesi Tıp Fakültesi Medikal Onkoloji kliniğinde takip edilen lokal ileri evre IIIA ve IIIB KHDAK 47 hastanın dosyaları retrospektif olarak değerlendirildi. 
Bulgular: Primer tedavi olarak 27 (\%57) hasta definitif kemoradyoterapi (KRT), 20 (\%43) hastaya cerrahi tedavisi uygulanmıştı. KRT uygulanan hastaların, performans durumunun $(\mathrm{p}=0.010)$ istatistiksel olarak anlamlı derecede daha kötüydü, aktif sigara içiminin $(\mathrm{p}=0.033)$ daha fazla olduğu ve daha ileri lenf nodu evresine ( $\mathrm{p}=0.052)$ sahip olduğu görülmüştür. Tek değişkenli analizde lenf nodu durumu $(p=0.011)$, hastaların performans durumu $(p=0.0247)$ ve hastaların tedavi modalitesi $(p=0.001)$ sağ kalımı etkileyen prognostik faktörler olarak tespit edilmiştir. Hastaların 1 yıllık genel sağ kalım oranları ve medyan sağ kalımı, cerrahi uygulanan grupta sirasıyla $85 \%$ ve 23 ay, definitif KRT uygulananlarda $41 \%$ ve 10 ay olarak tespit edilmiştir. Çok değişkenli analizde cerrahi yapılması KRT'ye göre bağımsız daha iyi prognostik faktör olarak belirlenmiştir (HR: 2.72, 95\% CI: 1.27-5.82, p=0.010).

Sonuç: Evre III KHDAK hasta grubunda klinik deneyimimiz sonucunda rezektabl olan hastaların sonuçlarının daha iyi olduğu görülmektedir. Mediasten lenf nodu tutulum bölgesi özellikle N3 lenf nodu bölgesi ve hasta performans1 evre III KHDAK' inde prognozu belirleyen önemli faktörlerdendir.

Anahtar sözcükler: Küçük hücre dışı akciğer kanseri, cerrahi, kemoradyoterapi

\section{INTRODUCTION}

Lung cancer is one of the most common cancers in the world and has a high mortality rate. It is estimated that there are 2.1 million new cases of lung cancer in 2018 and this cancer type caused 1.8 million deaths worldwide ${ }^{1}$. Approximately $85 \%$ of all the lung cancers are NSCLC and approximately $35 \%$ of these cases are diagnosed during the locally advanced stage ${ }^{2}$. More than $60 \%$ of patients with local advanced NSCLC die due to lung cancer ${ }^{3}$. Despite improved treatment strategies, overall survival rates are low, and treatment of stage III local advanced NSCLC is difficult, and the selection of the treatment modality still remains controversial. The chance of success in the treatment via single treatment options (chemotherapy, radiotherapy, surgery) is quite low. While stage IIIA disease is classified as T1-2-N2, T3-N1, and T4-N0-1, stage IIIB disease is classified as T1-2-N3 and T3-4-N2 ${ }^{4}$. Stage IIIB disease is assessed as inoperable and is usually treated with CRT ${ }^{5}$. Trimodal therapy including induction CRT and subsequent surgery is a potential treatment option in local advanced NSCLC. Although this strategy is not considered as a standard treatment, there are some patient subgroups in some studies from which good results have been obtained ${ }^{6-8}$. Some studies have not revealed the additional effect of surgery performed by adding RT to induction CRT compared to surgery performed only after CRT ${ }^{9}$, ${ }^{10}$. However, even after this intensive treatment, there are patient groups developing recurrence after surgery. At this stage, there is a need for new treatment modalities which will increase the overall survival and disease-free survival with minimal side effects and limit the development of distant metastasis.

The aim of the present study is to retrospectively evaluate the survival results of surgical patients undergoing CRT as the primary treatment in stage IIIA and B local advanced NSCLC who were treated in our clinic.

\section{MATERIAL AND METHODS}

The files of the patients, who were treated at the clinic of Medical Oncology of Gazi University Faculty of Medicine between February 2016 and May 2018 and whose radiological stage was local advanced stage IIIA and IIIB NSCLC during the diagnosis, were evaluated retrospectively. In the present study, patients with early stage and metastatic stage were excluded from the study. The performance status of the patients was assessed according to the performance status of ECOG (The Eastern Cooperative Oncology Group).

Planning of the RT of the patients was made over thoracic tomography or PET-CT. The tumor or lymph nodes with the diameter of the short axis exceeding $1 \mathrm{~cm}$ visible in thoracic $\mathrm{CT}$ or the primary mass or lymph nodes involving FDG in PET-CT were marked as GTV (gross target volume). In CTV (the clinical target volume) marking, adenocarcinomas were detected with 0.8 $\mathrm{cm}$ margin and squamous cell carcinomas with 0.6 $\mathrm{cm}$ margin. Different margins were used for each patient in PTV marking (the planning target volume). The RT of the patients was applied in radiation dosage of median 665.45 Gy (60-66.6 Gy) and in conventional dosages of 1.8-2 Gy daily.

The Statistical Package for Social Sciences (SPSS) for Windows 23.0 (SPSS, Inc., Chicago, IL, USA) was used for the statistical analysis. The descriptive analysis was expressed in frequency, mean and standard deviation. Frequencies were compared with the Chi-Square test for categorical variables. The Student-t test was used to compare continuous variables. The Mann-Whitney $U$ test was used for groups which were not normally distributed. The survival rates were calculated according to the Kaplan-Meier method. A multivariate analysis (Cox regression analysis) was used to evaluate the independent risk factors 
that affected survival. The $p$ value of $\leq 0.05$ was accepted as statistically significant.

\section{RESULTS}

The data of $20(43 \%)$ patients with local advanced stage IIIA and IIIB NSCLC, who received CRT as the primary treatment, and $27(57 \%)$ patients to whom surgery was applied, were recorded. The general characteristics of the patients during diagnosis are summarized in Table 1 . The performance status $(\mathrm{p}=0.010)$, smoking $(\mathrm{p}=0.033)$, and lymph node status $(\mathrm{p}=0.052)$ were found to be significantly different between the groups.

Table 1. Demographic characteristics of the patients

\begin{tabular}{|c|c|c|c|c|}
\hline & $\begin{array}{l}\text { All patients } \\
\mathrm{n}=47(\%)\end{array}$ & $\begin{array}{l}\text { CRT group } \\
\mathrm{n}=27(\% 57)\end{array}$ & $\begin{array}{c}\text { Surgery group } \\
\mathrm{n}=20(\% 43)\end{array}$ & $\mathrm{p}$ value \\
\hline Age (years) & $\begin{array}{c}65 \\
(36-81)\end{array}$ & $\begin{array}{c}65 \\
(44-81)\end{array}$ & $\begin{array}{c}62 \\
(36-76)\end{array}$ & 0.375 \\
\hline $\begin{array}{l}\text { Gender } \\
\text { Female } \\
\text { Male }\end{array}$ & $\begin{array}{l}4(10) \\
43(90)\end{array}$ & $\begin{array}{c}4(15) \\
23(85)\end{array}$ & $20(100)$ & 0.098 \\
\hline $\begin{array}{l}\text { Performance status } \\
0-1 \\
2 \text { and above }\end{array}$ & $\begin{array}{l}36(77) \\
11(23)\end{array}$ & $\begin{array}{l}18(67) \\
9(33)\end{array}$ & $\begin{array}{c}18(90) \\
2(10)\end{array}$ & 0.010 \\
\hline $\begin{array}{l}\text { Tumor status } \\
\text { T1-2 } \\
\text { T3-4 }\end{array}$ & $\begin{array}{l}14(30) \\
33(70) \\
\end{array}$ & $\begin{array}{c}8(30) \\
19(70)\end{array}$ & $\begin{array}{c}6(30) \\
14(70)\end{array}$ & 0.613 \\
\hline $\begin{array}{l}\text { Node status } \\
\text { N0 } \\
\text { N1 } \\
\text { N2 } \\
\text { N3 }\end{array}$ & $\begin{array}{c}5(11) \\
10(21) \\
28(60) \\
4(8)\end{array}$ & $\begin{array}{c}1(4) \\
5(18) \\
17(63) \\
4(15)\end{array}$ & $\begin{array}{c}4(20) \\
5(25) \\
11(55) \\
\quad-\end{array}$ & 0.052 \\
\hline $\begin{array}{r}\text { Stage } \\
\text { IIIA } \\
\text { IIIB } \\
\end{array}$ & $\begin{array}{l}28(60) \\
19(40)\end{array}$ & $\begin{array}{l}13(48) \\
14(52)\end{array}$ & $\begin{array}{l}15(75) \\
5(25) \\
\end{array}$ & 0.059 \\
\hline $\begin{array}{l}\text { Primary tumor } \\
\text { localization } \\
\text { Right lung } \\
\text { Left lung }\end{array}$ & $\begin{array}{l}28(60) \\
19(40)\end{array}$ & $\begin{array}{l}18(67) \\
9(33)\end{array}$ & $\begin{array}{l}10(50) \\
10(50)\end{array}$ & 0.197 \\
\hline $\begin{array}{l}\text { Histology } \\
\text { Squamous cell } \\
\text { carcinoma } \\
\text { Adenocarcinoma } \\
\text { Other }\end{array}$ & $\begin{array}{c}26(55) \\
13(10) \\
8(17) \\
\end{array}$ & $\begin{array}{c}14(52) \\
10(37) \\
3(11) \\
\end{array}$ & $\begin{array}{c}3(19) \\
12(60) \\
5(25) \\
\end{array}$ & 0.178 \\
\hline $\begin{array}{l}\text { Smoking } \\
\text { No } \\
\text { Yes } \\
\text { Ex-smoker }\end{array}$ & $\begin{array}{c}3(6) \\
28(60) \\
16(34)\end{array}$ & $\begin{array}{c}2(7) \\
20(74) \\
7(19)\end{array}$ & $\begin{array}{c}1(5) \\
8(40) \\
11(55)\end{array}$ & 0.033 \\
\hline $\begin{array}{l}\text { Comorbidity } \\
\text { No } \\
\text { Yes }\end{array}$ & $\begin{array}{l}22(45) \\
25(55) \\
\end{array}$ & $\begin{array}{l}13(48) \\
14(52)\end{array}$ & $\begin{array}{c}9(45) \\
11(55)\end{array}$ & 0.533 \\
\hline Stage & & & & \\
\hline Stage IIIA & $28(60)$ & $13(48)$ & $15(75)$ & 0.059 \\
\hline Stage IIIB & $19(40)$ & $14(52)$ & $5(25)$ & \\
\hline
\end{tabular}

Data are median (range) or number (\%). 
Lobectomy was performed to $14(70 \%)$ patients and pneumonectomy to $6(30 \%)$ patients surgically. Of 20 patients who underwent surgery, 5 (20\%) had neoadjuvant CT and 15 (75\%) had adjuvant CT/RT. Of the patients to whom adjuvant treatment was applied, 9 patients $(45 \%)$ underwent $\mathrm{CT}+\mathrm{RT}$ and 6 patients $(43 \%)$ underwent CT. One out of 5 patients, who did not receive adjuvant treatment, died in the postop period and 2 patients had no treatment due to their general condition disorders. Other two patients did not come for follow-up appointments. Of 27 patients undergoing CRT, induction CT was applied to 1(4\%) and consolidation CT was applied to 7 (26\%). Two patients in the CRT group died during the treatment and 2 patients were unable to complete the treatment due to general condition disorder. One patient did not come for the follow-up after the primary treatment.

In the univariate analysis, the 1-year overall survival rates and median survival rates were determined as $85 \%$ and 23 months in the surgery group, and $41 \%$ and 10 months in the definite CRT group $(\mathrm{p}=0.001)$. Figure 1 shows median overall survival plot. In addition, the status of the lymph node $(\mathrm{p}=0.011)$ and the performance status of the patients $(\mathrm{p}=0.0247)$ was determined as the other factors affecting the prognosis. Table 2 shows the prognostic factors determined in the univariate analysis. In the multivariate analysis, surgical application predicted the prolonged overall survival as statistically significant compared to CRT (HR: 2.72, 95\% CI: 1.27-5.82, $p=0.010$ ).

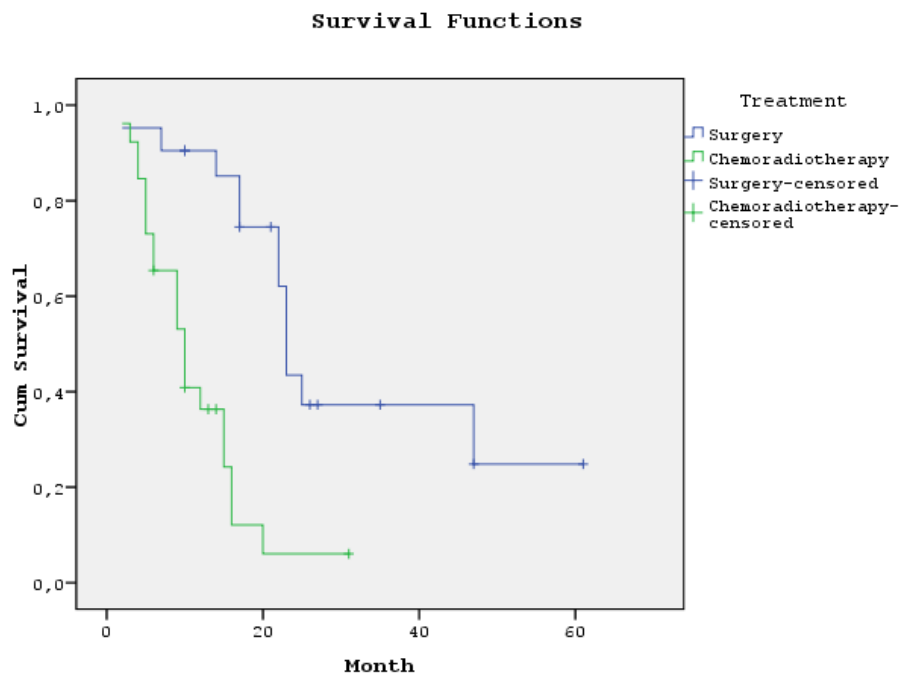

Figure 1. Survival curves according to the treatment of patients with stage III Non-small cell lung cancer

Table 2. Prognostic factors of the patients in the univariate analysis.

\begin{tabular}{lccc}
\hline & $\begin{array}{c}\text { 1-year overall } \\
\text { survival (month) }\end{array}$ & $\begin{array}{c}\text { Median survival } \\
(\text { month })\end{array}$ & p value \\
\hline Treatment & 85 & 23 & $<0.001$ \\
$\quad$ Surgery & 41 & 10 & 0.068 \\
Chemoradiotherapy & 69 & 15 & \\
\hline Stage & 47 & 11 & 0.014 \\
Stage IIIA & not reached & \\
Stage IIIB & 75 & 16 & \\
\hline Nod & 57 & & \\
Negative & & & \\
Positive & & & \\
\end{tabular}




\begin{tabular}{lccc}
\hline Performance status & & & \\
ECOG $0-1$ & 65 & 9 & 0.027 \\
ECOG 2 and above & 32 & 9 & \\
\hline
\end{tabular}

\section{DISCUSSION}

In general, 5-year survival rates of locoregional therapies (only with surgery or RT) in stage IIIA and IIIB local advanced period of NSCLC are evaluated as $15 \%$ and $5 \%$, respectively ${ }^{11}$. In these patients, the prognosis is poor due to the high rate of inoperability and the emergence of systemic micro-metastases. Even though most of the patients are treated with surgery or RT, they die due to local recurrence or distant metastasis. Therefore, it is difficult to improve survival with a single treatment method by controlling both the primary tumor and occult systemic metastases. In this group of patients with low survival rates, it is required to provide both local and systemic control via multimodal treatment methods.

In a study evaluating the results of trimodal therapy, 48 patients with stage IIIA and IIIB local advanced NSCLC received neoadjuvant 2 cycles of CT, which was followed by CRT ${ }^{12}$. Then, 39 of the patients were able to have surgery. In this study, the median survival was evaluated as 23 months and the 3- and 5-year survival rates as $41.7 \%$ and $31.8 \%$, respectively. In this study, complete resection of the patients and pathological response rates in the surgical specimen are determined as the independent predictor factors for survival. Although no complete comparison could be made due to the absence of the control group, it was observed that the overall survival results were generally longer than the other studies in the literature.

In another study, the patients with stage IIIA/N2 NSCLC underwent induction CT. Of the patients divided into two groups, one group underwent surgery after RT and the other group underwent direct surgery. No additional contribution of preoperative RT addition to neoadjuvant $\mathrm{CT}$ can be shown in terms of disease-free survival and overall survival ${ }^{13}$. Again, two randomized trials could not show the benefit of adding CRT to neoadjuvant $\mathrm{CT}$ alone ${ }^{9,10}$.

The role of surgery in stage III NSCLC is still unclear. In a randomized phase III study comparing definitive CRT alone and surgery after induction CRT, the patients with stage III A/N2 were included in the study (14). An improvement close to statistical significance was observed in disease-free survival in the surgery group (Respectively, 12.8 months in the surgery group and 10.5 months in the definitive CRT group, $\mathrm{p}=$ 0.017). However, no difference was observed in the overall survival between two groups (23.6 months and 22.2 months respectively, $\mathrm{p}=0.24$ ). While treatment-related deaths were higher in the surgery group, grade 3-4 side effects such as neutropenia and esophagitis were more common in the definitive CRT group.

Again, in another randomized study, patients with stage III A/N2 NSCLC were allocated to the surgical and RT arms after induction CRT (15). 5year overall survival was found to be similar in the surgery arm and in the RT arm (15.7\% and $14 \%$, respectively). Also, no difference was found in terms of overall survival (16.4 months and 17. 5 months, respectively). As a result, the superiority of surgery to RT cannot be demonstrated in the present study, but it can be seen that RT may take the place of surgery in such patients with lower mortality and morbidity rates.

In the present study, the patients diagnosed with stage IIIA and IIIB local advanced NSCLC, who underwent surgery as the primary treatment, and the patients undergoing definitive CRT were evaluated retrospectively. Although the number of patients was limited, it was found that 1-year survival rates of the patients, who underwent surgery, were significantly higher than the patients receiving CRT $(85 \%$ and $41 \%$, respectively). Similarly, overall survival was longer in the surgery group (23 months and 10 months, respectively).

In the study, surgical treatment was also determined as the independent prognostic factor. When examining the distribution of patients, patients who were older, had worse performance and had a higher number of lymph nodes were included mostly in the CRT group. In addition, as is seen in univariate analysis, lymph node and the performance status of patients were determined as the factors affecting survival. It was found that patients with poor performance and positive lymph nodes had lower survival rates. It was thought that survival results of the patients in the CRT group were shorter than the values reported in the literature due to the tendency for the patients, for whom surgery would not be applied due to their poor general condition, additional disease or N3 disease, to receive CRT. This can be associated with the fact that the number of 
patients was insufficient and two patient groups were not similar in many respects.

As a result, in this patient group with difficult management and low success rate of treatment, the chance of treatment in the patients having better performance, lower lymph node stage and resectable tumor increases.

There are some limitations to the study. The first one is that the study was not a randomized clinical trial, which did not allow the comparison of the patient groups with similar characteristics. The second one is an insufficient number of patients. The third is the failure to evaluate the toxicity of the treatments.

\section{REFERENCES}

1. Bray F, Ferlay J, Soerjomataram I, et al. Global cancer statistics 2018: GLOBOCAN estimates of incidence and mortality worldwide for 36 cancers in 185 countries. CA Cancer J Clin. 2018 Nov;68(6):394-424.

2. Govindan R, Bogart J, Vokes EE. Locally advanced non-small cell lung cancer: the past, present, and future. J Thorac Oncol. 2008;3:917-28.

3. Goldstraw P, Crowley J, Chansky K, et al. The IASLC Lung Cancer Staging Project: proposals for the revision of the TNM stage groupings in the forthcoming (seventh) edition of the TNM Classifi cation of malignant tumours. J Thorac Oncol 2007; 2: 706-14.

4. National Comprehensive Cancer Network: NCCN Clinical Practice Guidelines in Oncology: Non-Small Cell Lung Cancer. Version 3.2019. Fort Washington, Pa: National Comprehensive Cancer Network, 2018.

5. Furuse K, Fukuoka M, Kawahara M, et al. Phase III study of concurrent versus sequential thoracic radiotherapy in combination with mitomycim, vindesine, and cisplatin in unresectable stage III non-small-cell lung cancer. J Clin Oncol 1999; 17:2692-9.

6. Shien K, Toyooka S, Kiura K, Matsuo K, Soh $\mathrm{J}$, Yamane $\mathrm{M}$, et al. Induction chemoradiotherapy followed by surgical resection for clinical $\mathrm{T} 3$ or $\mathrm{T} 4$ locally advanced non-small cell lung cancer. Ann Surg Oncol. 2012;19:2685-92.

7. Lococo F, Cesario A, Margaritora S, Dall'Armi V, Nachira D, Cusumano G, et al. Induction therapy followed by surgery for T3T4/N0 non-small cell lung cancer: long-term results. Ann Thorac Surg. 2012;93:1633-40.
8. Toyooka S, Kiura K, Takemoto M, Oto T, Takigawa N, Fujiwara T, et al. Long-term outcome of induction chemoradiotherapy with docetaxel and cisplatin followed by surgery for non-small-cell lung cancer with mediastinal lymph node metastasis. Interact Cardiovasc Thorac Surg. 2012;14:565-9.

9. Katakami N, Tada H, Mitsudomi T, et al. A phase 3 study of induction treatment with concurrent chemoradiotherapy versus chemotherapy before surgery in patients with pathologically confi rmed N2 stage IIIA nonsmall cell lung cancer (WJTOG9903). Cancer 2012; 118: 6126-35.

10.Girard N, Mornex F, Douillard JY, et al. Is neoadjuvant chemoradiotherapy a feasible strategy for stage IIIA-N2 non-small cell lung cancer? Mature results of the randomized IFCT-0101 phase II trial. Lung Cancer 2010; 69: 86-93.

11. Mountain CF. A new international staging system for lung cancer. Chest 1986; 89(suppl 4):255-83.

12. Li J, Dai $\mathrm{CH}, \mathrm{Yu} \mathrm{LC}$, et al. Result of trimodality therapy in patients with stage IIIA (N2-bulky) and stage IIIB non-small-cell lung cancer. Clin Lung Cancer. 2009 Sep;10(5):353-9.

13.Pless M, Stupp R, Ris HB, et al. Induction chemoradiation in stage IIIA/N2 non-smallcell lung cancer: a phase 3 randomised trial. Lancet 2015; 386: 1049-56.

14. Albain KS, Swann RS, Rusch VW, et al. Radiotherapy plus chemotherapy with or without surgical resection for stage III nonsmall-cell lung cancer: a phase III randomised controlled trial. Lancet 2009; 374: 379-86.

15.Van Meerbeeck JP, Kramer GW, Van Schil $\mathrm{PE}$, et al. Randomized controlled trial of resection versus radiotherapy after induction chemotherapy in stage IIIA-N2 non-small-cell lung cancer. J Natl Cancer Inst 2007; 99: 44250 . 